\title{
SOME ASPECTS OF IMPROVEMENT OF GRASSLAND PRODUCTION FOR GRAZING OF SHEEP
}

\author{
D.Ružić-Muslić ${ }^{1}$, Z. Bijelić ${ }^{1}$, M. P. Petrović ${ }^{1}$, M. M. Petrović ${ }^{1}$, , V. \\ Pantelić $^{1}$, P. Perišićc ${ }^{2}$ V. Caro-Petrović ${ }^{1}$ \\ ${ }^{1}$ Institute for Animal Husbandry, Belgrade-Zemun, 11080, Serbia \\ ${ }^{2}$ Faculty of Agriculture, University of Belgrade, Belgrade, Serbia \\ Corresponding author: muslic.ruzic@.gmail.com \\ Review paper
}

\begin{abstract}
Grasslands represent significant natural resource with important role in economy and ecology of every country. Properly cultivated and utilized grasslands provide cheap and high quality food for sheep, which they easily transfer into milk and meat. However, extensive management has caused degradation of pasture areas. Improvement of production of forage plants on pastures is achieved by using melioration measures, primarily fertilization. Fertilization is important also from the aspect of increase of yield and quality of forage plants. The effect of application of fertilizer depends on the present plant species in the mixture. Application of nitrogen mineral fertilizers in mixtures reduces the nitrogen fixating abilities of leguminous species, which leads to the diminishing of their competitive abilities and favouring of the grass component in the mixture. Use of excessive quantities of $\mathrm{N}$ fertilizer in plants causes the accumulation of nitrates, as a unfavourable quality parameter in plant tissues, which can have harmful effect on animal health. Therefore, attention should be focused on application of $\mathrm{N}$ fertilizers, which should be harmonized with the plant requirements, so that used quantities are not excessive and harmful. Objective of this paper is to point out the significance of fertilization as one of the most important melioration measures.
\end{abstract}

Key words: grasslands, fertilization, nutrition, sheep

\section{Introduction}

Decreasing trend has been present in sheep production in Serbia in recent years, as a consequence of the process of depopulation, abandoning of agricultural production and in general demographic emptying of villages, as well as existing system in sheep production based on traditional principles (Ružić-Muslić et al., 
$2006 a, 2006 b$ ). On the other hand, hilly-mountainous regions of Serbia disposes with significant agricultural-geographic potentials which can be best utilized for production of healthy, safe and high quality food such as lamb meat and sheep milk (Ružić-Muslić et al., 2007, 2006a).

According to statistical data from year 2010, 1.475 .000 heads of sheep are reared in Serbia. Main pre-condition of rational utilization of existing production capacities in sheep production is proper nutrition of sheep which includes, among other things, use of grasslands and use of the roughage of good quality (RužićMuslić et al.,2011a, 2011b)

Grazing of sheep is traditional practice, but also necessity, so sustainable sheep production is not possible without the use of pastures (Petrovic P.M., 2007). Pasture has positive effect on animal health, increase of productivity and improvement of product quality, with the lowest possible costs, compared to housing in stables.

It is established that lamb meat obtained from animals kept on pasture has more favourable fatty acids ratio, which decreases the risk of coronary diseases. Linolenic acid is considered to be anti-cancerous and there are certain indications that it is more present in meat deriving from animals kept on pasture.

However, although ecologically desirable, extensive utilization of pasture areas causes their degradation (decrease of yields and quality) of grasslands.

Improvement of production of food on pastures is possible only with melioration of natural grasslands and by establishing of sown grasslands. The fertilization is of the greatest importance of all melioration measures.

\section{The effect of fertilization on increase of forage yield on pastures}

Results of numerous studies which referred to the possibility of and way of production intensification on pastures showed that one of the most efficient agrotechnical measures is use of fertilization.

Fertilization of grass-leguminous mixtures leads to increase of yield of green mass and dry matter. In the three year study of fertilization of alfalfa and cocksfoot mixture using complex $\mathrm{N}$ fertilizer lead to significant increase of yield compared to non-fertilized variants (Ocokoljić et al., 1974).

In the study of the impact of mineral fertilizers with and without nitrogen on yield of grassland, Komarek et al. (2007) concluded that fertilizers with nitrogen increased the dry matter yield. By adding of $90 \mathrm{kgN} \mathrm{ha}^{-1}$ yield increased from 6,72 to $8,61 \mathrm{t} \mathrm{ha}^{-1}$, and by adding $180 \mathrm{kgN} \mathrm{ha}^{-1}$ to $9,75 \mathrm{t} \mathrm{ha}^{-1}$. Alibegović-Grbić et al. (2004) indicate that with the application of $80 \mathrm{~kg} / \mathrm{ha}$ of nitrogen on meadows located in hilly regions the yield increased from 6,05 to $11,30 \mathrm{t} / \mathrm{ha}$ 
However, due to nitrogen fixating abilities of leguminous plants, the quantities of nitrogen necessary for realization of certain yield of grassland forage are significantly reduced. In many studies it was proved that yields of mixtures without fertilization had realized identical even higher yields compared to pure crops fertilized with certain nitrogen quantities.

Malhi et al. (2002), investigated the pure crop of brome grass and alfalfa and their mixture in different ratios $(2: 1 ; 1: 1 ; 1: 2)$ and five fertilization treatments $(0$, $50,100,150$ and $200 \mathrm{~kg} \mathrm{ha}^{-1} \mathrm{~N}$ ) and established that dry matter yield of pure grass crops is directly depending on the amount of added nitrogen. Addition of $50 \mathrm{~kg} \mathrm{ha}^{-1}$ of nitrogen caused increase of yield by $75 \%$, and addition of $200 \mathrm{~kg} \mathrm{ha}^{-1}$ of nitrogen induced increase by $255 \%$. Mixtures without fertilization compared to pure grass crop resulted in yields which were similar to yields of pure grass crop fertilized with $150 \mathrm{~kg} \mathrm{ha}^{-1} \mathrm{~N}$.

In their study of the pure crop of English ryegrass fertilized with 0, 100, 200, 300 and $400 \mathrm{~kg} \mathrm{ha}^{-1}$ of nitrogen, and mixture of alfalfa and cocks foot and red clover and English rye grass without fertilization, Deprez et al. (2004) have concluded that mixtures have realized similar yields as the pure grass crops fertilized with $400 \mathrm{~kg} \mathrm{ha}^{-1} \mathrm{~N}$. Pure crop of English ryegrass fertilized with maximum amount of nitrogen realized yield of 11,5-16,5 $\mathrm{t} \mathrm{ha}^{-1}$, and mixtures without fertilization, alfalfa and cocksfoot 11,6-14,0 tha ${ }^{-1}$, and red clover and English ryegrass $12,3-15,1 \mathrm{tha}^{-1}$.

Nitrogen quantities in the fertilized must be adjusted to plant requirements. If this amount exceeds their requirements, then adverse and opposite effect can occur and cause decrease of yield.

Mixture of white clover and meadow fescue without fertilization realized higher yield of 5,19 $\mathrm{t} \mathrm{ha}^{-1}$ of dry matter compared to pure crop of meadow fescue fertilized with $100 \mathrm{~kg} \mathrm{ha}^{-1} \mathrm{~N}$. Addition of nitrogen to the mixture in the amount of 50 and $100 \mathrm{~kg} \mathrm{ha}^{-1}$ influences the decrease of yield (Razec et al., 2002).

The effect of fertilizer application depends on the present plant species in the mixture, since not all species respond in the same way to application of mineral fertilizers. Alfalfa compensates most of its nitrogen requirements through nitrogen fixation. In general, increase of dose of nitrogen mineral fertilizers leads to decrease of nitrogen fixation (Adamovich and Adamovicha, 2003), and consequently to decrease of the share of leguminous plant in grass-leguminous mixtures to the advantage of the grass component (Frankow-Lindberg, 1987; Höglind and Frankow-Lindberg, 1998; Griffin et al., 2002; Alibegović-Grbić et al., 2004).

The application of nitrogen mineral fertilizers to mixtures reduces the nitrogen fixation abilities of leguminous species, which leads to diminishing of their competitive abilities and favouring of the grass component in the mixture (Nuttall et al., 1991). According to Berdahl et al. (2001; 2004), addition of nitrogen mineral fertilizers in the amount of $50 \mathrm{kgN} \mathrm{ha}{ }^{-1}$ has no effect on increase of the mixture 
yield, but only on the share of the grass in the mixture. In average, for three year period, nitrogen fertilization in the amount of $89,6 \mathrm{~kg} \mathrm{ha}^{-1}$ reduced the share of white clover in the mixture by $50 \%$ (Stout et al., 2001).

Part of the nitrogen fixated by leguminous plants in the mixture is given to grasses. Transfer of $\mathrm{N}$ from leguminous plants to grasses, in the mixture, occurs by decomposing of leguminous root remains and direct release into the rhizosphere of nitrogen compounds absorbed by grasses. The amount of nitrogen transferred in this way to grasses amounts to $10 \%$ (Gebhart et al., 1993), to $80 \%$ of total nitrogen in grasses (Berdahl et al., 2001). Exchange of nitrogen is the greatest where the crops are most dense, and it can occur even on a distance of $20 \mathrm{~cm}$ (Brophy et al., 1987).

The efficiency of nitrogen utilization from nitrogen fixation, as well as from mineral fertilizers, in forming of yield of dry matter of the grassland is different and depends on the amount of added mineral nitrogen. Mixture with equal share of species, when fertilized with $50 \mathrm{kgN} \mathrm{ha}^{-1}$ resulted in yield of $14,8 \mathrm{tha}^{-1} \mathrm{DM}$, when fertilized with $150 \mathrm{kgN} \mathrm{ha}^{-1}-16 \mathrm{t} \mathrm{ha}^{-1}$, and when fertilized with the highest amount of fertilizer of $450 \mathrm{~kg} \mathrm{ha}^{-1}$ yield was $17,7 \mathrm{t} \mathrm{ha}^{-1}$. The efficiency of nitrogen utilization from nitrogen fixation in forming of yield is the highest when the lowest amount of fertilizer is applied and amounts to $48 \%$, whereas when $450 \mathrm{~kg} \mathrm{ha}^{-1}$ of fertilizer was used the efficiency is only $14 \%$. The efficiency of utilization of nitrogen for forming of $1 \mathrm{~kg}$ of dry matter is the highest with application of $50 \mathrm{kgN}$ $\mathrm{ha}^{-1}$. With $1 \mathrm{~kg} \mathrm{~N}$ yield of $261,2 \mathrm{~kg}$ DM was realized, and with fertilization of 450 $\mathrm{kgN} \mathrm{ha}^{-1}$, with $1 \mathrm{~kg} \mathrm{~N}$ 41,2 kg DM was created (Nifeler et al., 2008).

\section{The effect of fertilization on improvement of the forage quality from pastures}

Fertilization has significant impact on the forage quality (directly and indirectly). Direct improvement of the quality is manifested by increase of the content of nutrients in the plants (proteins, vitamins, minerals, carotene, etc.). Application of $\mathrm{N}$ complex fertilizers expressed significant effect on increase of the share of crude proteins in the mixture of alfalfa and cocksfoot by 17,6\% (Ocokoljić et al., 1974).

Jeremić and Stossić (1981), in their study of the chemical composition of alfalfa, meadow fescue and their mixtures with three levels of NPK fertilization, have established that by increasing the amount of nitrogen from 30 to $90 \mathrm{~kg} \mathrm{ha}^{-1}$ the increase of total nitrogen in above ground plant parts increases. Mixtures of alfalfa and meadow fescue contain more proteins than pure meadow fescue crop, whereas with abundant $\mathrm{N}$ fertilization this content reaches the value of the content in alfalfa. The nitrogen amount of $450 \mathrm{~kg} \mathrm{ha}^{-1}$ induced the increase of crude protein content in 
forage of bird's foot trefoil and cocksfoot by 15,43\%, and decrease of NFE by 13,17\%, whereas the fibre content remained unchanged (Ocokoljić et al., 1984a).

Stringer et al. (1996) have established that the fertilization decreased the content of crude fibre by $11-16 \mathrm{~g} \mathrm{~kg}^{-1}$ in the mixture. Maximum yield of crude proteins was in the range from 811 to $2469 \mathrm{~kg} \mathrm{ha}^{-1}$, and average yield with nitrogen amount of $448 \mathrm{~kg} \mathrm{ha}^{-1}$ was by 1,02- 7,63 times higher compared to yield of crude proteins without fertilization.

Indirect improvement of the forage quality is manifested in the change of the floristic composition, domination of plants of higher nutritional value and suppression of plants of lower quality (Vučković, 2004). Fertilization increases the competitive ability of high quality plant species which enables radical change in the floristic composition of the pasture and suppression of weeds in them (Alibegović-Grbic et al., 2005). This is the method how floristic composition is regulated, which is actually reducing to minimum and suppressing of undesirable species and favouring of better grass and leguminous species. Considering different biological properties of species and their relation to ecological conditions, Klapp (1971) points out that no fertilization system can satisfy the requirements of all species, which is consequence of natural selection of plants in regard to the use of mineral substances. Numerous studies show that in our conditions, NPK is mostly used with the component ratio 1-2:1:1 (Vučković, 1999). Phosphorus and potassium component promote the share and development of leguminous plants, slow down the weeds, whereas nitrogen forces grasses, eliminates leguminous plants. Stošić et al. (2006) confirm the importance of phosphorus in production of biomass, and conclude that if grasslands have leguminous plants, phosphorus fertilizers alone, or in combination with potassium fertilizers, contribute to the increase of their share. In general, application of fertilizer significantly influences the share of useful grasses (Poaceae) and leguminous plants (Fabaceae), and reduces the share of herbaceous plants in total mass of pasture. Increase of share of leguminous plants by $10 \%$, leads to increase of protein amount in forage by 1 to $1,5 \%$ (Šoštarić Pisačić and Kovačević, 1968). It is desirable, as stated by said authors, that share of leguminous plants within a community be $15-20 \%$.

According to research results of Ivanek (1977), the greatest effect of NPK fertilizer on pastures is achieved after the first application year. In addition to the type and amount of used fertilizer, time of application is also very important. Stošić et al. (2006) have studied the effect of the quantity and time of fertilizer application on yield of natural grasslands on the territory of Sjenica-Pešter plateau. The results are presented in table 1 
Table 1. The effect of the quantity and time of fertilizer application on yield of natural grasslands DM,t/ha, Stošić et al. (2006)

\begin{tabular}{|l|c|c|c|c|}
\hline \multirow{2}{*}{$\begin{array}{l}\text { Municipality } \\
\text { Village }\end{array}$} & \multicolumn{3}{|c|}{ Treatments } \\
\cline { 2 - 5 } & Unfertilized & $\begin{array}{l}\text { N30P30K30 } \\
\text { In spring }\end{array}$ & $\begin{array}{l}\text { N30 in fall+ } \\
\text { N30P30K30 } \\
\text { in spring }\end{array}$ & $\begin{array}{l}\text { N60P30K30 } \\
\text { In spring }\end{array}$ \\
\hline Tutin & 2,52 & 3,75 & 5,44 & 8,13 \\
Melaje & 3,75 & 5,62 & 6,09 & 7,52 \\
Leskova & 3,14 & 4,68 & 5,76 & 7,82 \\
Average & & & & \\
\hline Sjenica & 3,64 & 5,63 & 6,25 & 6,88 \\
Draževiće & 3,88 & 4,69 & 5,63 & 7,51 \\
Kokošiće & 4,22 & 5,84 & 6,87 & 7,19 \\
Trijebine \\
Average
\end{tabular}

Data in the table present the average increase of yield, by application of fertilization, on all five locations was $1,53 \mathrm{tha}^{-1}$ of hay. In treatments where nitrogen fertilizer was applied in the fall, yields were lower compared to the variant when all quantities of nitrogen fertilizer were applied before the vegetation - spring. Differences in the yields between fall and spring application of nitrogen fertilizers clearly indicate that during fall and winter the loss of nitrogen by leaching and denitrification occurred (Stošić et al., 2006). It can be justifiably concluded that fertilizer should only be applied in spring, before the start of vegetation, in order to avoid loss of applied nutrients, especially nitrogen.

Excessive application of nitrogen mineral fertilizers can have adverse effect on forage quality. Increase of available nitrogen in the soil solution influences the increase of nitrate uptake in plants and leads to its accumulation in plant tissues. Nitrates accumulate mainly in the stem, in the bottom third part of the stem, also leaves, flower and seed (Stanton, 2001).

Nitrate content in plant material becomes potentially dangerous when nitrogen doses become significantly higher than what is necessary to ensure satisfactory yield of dry matter. Nitrate content varies from cut to cut, and depending on the type of crops and type of fertilization. In case of English ryegrass, maximum nitrogen uptake is in the fertilization range from $400-600 \mathrm{~kg} \mathrm{ha}^{-1}$, and in case of mixture 300-400 $\mathrm{kg} \mathrm{ha}^{-1}$. Maximum nitrate concentration established in pure crop of English ryegrass fertilized with $400 \mathrm{kgN} \mathrm{ha}^{-1}$ of $9345 \mathrm{mg} \mathrm{kg}^{-1} \mathrm{DM}$, and in the mixture of white clover and English ryegrass fertilized with $300 \mathrm{kgN} \mathrm{ha}^{-1}$ of 6255 $\mathrm{mg} \mathrm{kg}{ }^{-1} \mathrm{DM}$ (Shiel et al., 1999).

Jeremić and Stošić (1981) have established that in the mixture of alfalfa and meadow fescue (70:30) the content of nitrate nitrogen increases with the increase of nitrogen dose in nutrition. With $30 \mathrm{kgN} \mathrm{ha}^{-1}$ content of nitrate nitrogen amounts 
to $19 \mathrm{mg} 100 \mathrm{~g}^{-1}$, with $90 \mathrm{kgN} \mathrm{ha}^{-1}$ content increases to $24 \mathrm{mg} 100 \mathrm{~g}^{-1}$, and when fertilized with $180 \mathrm{kgN} \mathrm{ha}^{-1}$ to $30 \mathrm{mg} 100 \mathrm{~g}^{-1}$.

Content of nitrate ion in plants is directly dependent on nitrate content in the soil (Ilin, 2000). Introduction of nitrogen mineral fertilizers into soil causes the increase of nitrate concentration in soil solution, which leads to increase of uptake and accumulation of nitrates in plants with toxic effect in ruminant nutrition (Petrović, 2003).

Nitrates accumulated in the soil also have unfavourable impact on nodulation and nitrogen fixation since they decrease the surface of the plant root, and hence number of root nodes (Hannaway and Shuler, 1993).

High concentration of nitrates in plants can lead to diminishing of the quality of livestock feed. Study of the $\mathrm{NO}_{3}^{-}$content in livestock food and milk by Marinković $i$ Grčić (1993) showed that the nitrate content is the lowest in concentrated food and ranges from $0-825 \mathrm{mg} \mathrm{kg}^{-1}$, and significantly higher in silage $0-1150 \mathrm{mg} \mathrm{kg}^{-1}$, and the highest in alfalfa hay $0-1700 \mathrm{mg} \mathrm{kg}^{-1}$. With the increase of nitrate content also the nitrate content in milk increases from $4,8-9,4 \mathrm{mg} \mathrm{kg}^{-1} \mathrm{DM}$.

Stoltenow and Lardy (1998) indicate that the concentration of $\mathrm{NO}_{3}{ }^{-}$in forage of up to $6500 \mathrm{mg} \mathrm{kg}^{-1}$ can be considered as harmless and safe for use. If nitrate concentrations in forage range from $6500-20000 \mathrm{mg} \mathrm{kg}^{-1}$ this should be taken into account in animal nutrition, and more concentrated nitrate free feed should be added into their diet. Content above $20000 \mathrm{mg} \mathrm{kg}^{-1}$ should be avoided since it is toxic for animals.

According to Adams et al. (1992) slightly lower concentrations of 1-3\% DM can cause acute poisonings in animals and are considered dangerous, therefore livestock should not be fed such livestock food.

Utilization of excessive amounts of $\mathrm{N}$ fertilizers causes in plants accumulation of nitrates, which is negative parameter of quality of plant tissues, and can have adverse effect on animal health condition. Therefore attention should be focused on application of $\mathrm{N}$ fertilizers, to keep it in harmonization with the plant requirements and avoid excessive and harmful quantities.

\section{Conclusion}

Main precondition of rational utilization of existing production capacities in sheep production is proper sheep nutrition which includes, among other things, utilization of grasslands and use of roughage of better quality.

- Extensive exploitation causes pasture degradation.

- Application of melioration measures, primarily fertilization, results in increase and improvement of yield and quality of forage from pastures. 
- The effect of fertilizer application depends on present plant species in the mixture.

- Increase of dose of nitrogen fertilizers influences reduced nitrogen fixation and simultaneously decrease in share of leguminous plants in grassleguminous mixtures favouring the grass component.

Use of excessive amounts of $\mathrm{N}$ fertilizer in plants causes accumulation of nitrates as unfavourable quality parameter in plant tissues, which can have detrimental effect on animal health.

\section{Acknowledgement}

This research is part of the Project EVB: TR-31053 financial supported by Ministry of Science and Technological Development of the Republic of Serbia

\section{Neki aspekti poboljšanja produkcije travnjaka za ispašu ovaca}

D.Ružić-Muslić, Z.Bijelić, M.P.Petrović, M.M. Petrović, V. Pantelić, P.Perišić, V. Caro-Petrović

\section{Rezime}

Travnjaci su značajan prirodni resurs koji ima važnu ulogu u ekonomiji i ekologiji svake zemlje.Pravilno negovani i iskorištavani ,travnjaci obezbeđuju jeftinu i kvalitetnu hranu za ishranu ovaca koju one uspešno transformišu u mleko i meso.

Međutim, ekstenzivno gazdovanje je uslovilo degradaciju pašnjačkih površina.Unapređenje proizvodnje krme na pašnjacima se postiže primenom meliorativnih mera, u prvom redu đubrenja. Đubrenje ima značajan uticaj na povećanje prinosa i kvaliteta krme. Efekat primene đubriva zavisi od prisutne biljne vrste $u$ smeši. Primena azotnih mineralnih đubriva u smešama, smanjuje azotofiksatorne sposobnosti leguminoznih vrsta, što dovodi do slabljenja njihovih konkurentnih sposobnosti i favorizovanja travne komponente u smeši.

Upotreba prevelikih količina $\mathrm{N}$ đubriva kod biljaka izaziva nagomilavanje nitrata, kao nepoželjnog parametra kvaliteta u biljnim tkivima, koji mogu da imaju štetno dejstvo na zdravstveno stanje životinja. Iz tih razloga treba pokloniti veliku pažnju primeni $\mathrm{N}$ đubriva, koja treba da bude u skladu sa potrebama biljaka, kako upotrebljene količine ne bi bile prevelike i štetne. 
Cilj ovog rada je bio da ukaže na značaj đubrenja kao jedne od najvažnijih meliorativnih mera.

\section{References}

ADAMOVICH A., ADAMOVICHA O. (2003): Productivity and forage quality of Festulolium/legume mixed swards in response to cutting frequency. Grassland Science in Europe, 8, 453-456.

ADAMS R.S., T. MCCARTY, AND L.J. HUTCHINSON.( 1992): Prevention and control of nitrate toxicity in cattle. Penn. State Dairy Anim. Sci. Publ. 92-107. Penn. State Univ., College Agric. Coop. Ext. Serv., University Park, PA.

ALIBEGOVIĆ-GRBIĆ S., ČIVIĆ H., BEZDROB M. (2004): Uticaj primene nižih doza azota $\mathrm{i}$ faze razvoja biljaka pri kosidbi na prinos suve materije i sirovih proteina sa travnjaka. Acta Agriculturae Serbica, IX, 17, 289-293.

ALIBEGOVIĆ-GRBIĆ S., ERIĆ P., VUČKOVIĆ S., ĆUPINA B., DUBLJEVIĆ R., IVANOVSKI P., PRENTOVIĆ T., GATARIĆ Đ., NEDOVIĆ B. (2005): Unapređenje proizvodnje krme na prirodnim travnjacima. Univerzitet u Sarajevu Poljoprivredni fakultet, 176.

BERDAHL J. D., KARU J. F., HENDRICKSON J. R. (2001): Dry matter yield of cool-seson Grass Monocultures andgrass-alfalfa binary mixtures. Agronomy Journal, 93, 463-467.

BERDAHL J., KARN J., HENDRICKSON J. (2004): Nutritive quality of coolseason grass monocultures and binary grass-alfalfa mixtures at late harvest. Agronomy Journal, 96, 4, 951-955.

BROPHY S.L., HEICHEL G.H., RUSSELLE M.P. (1987): Nitrogen transfer from forage legumes to grass in a systematic planting design. Crop Science, 27, 753-758.

DEPREZ B., LAMBERT R., DECAMPS C., PEETERS A. (2004): Production and quality of red clover (Trifolium pratense) and lucerne (Medicago sativa) in pure stand or in grass mixture in Belgium. Grassland Science in Europe, 9, 498-500.

FRANKOW-LINDBERG, B.E. (1987): Lucerne grass swards with different nitrogen application and grass components. Swedish Journal of Agricultural Research, 17, 179-184.

GEBHART L.D., CALL A.C., WEAVER W.R. (1993): Dinitrogen fixation and transfer in legume-crested wheatgrass mixtures. Journal of Range Management, 46, 431-435.

GRIFFIN T., GIBERSON E., WIEDENHOEFT M. (2002): Yield response of longterm mixed grassland swards and nutrient cycling under different nutrient sources and management regimes. Grass and Forage Science, 57, 268-278.

HANNAWAY B.D., SHULER E.P. (1993): Nitrogen fertilization in alfalfa production. Journal of Production Agriculture, 6, 1, 80-85. 
HÖGLIND, M., FRANKOW-LINDBERG, B. (1998): Growing point dinamics and spring growth of white clover in mixed sward and the effect of nitrogen application. Grass and Forage Science, 53, 338-345.

ILIN Ž., ĐUROVKA M., MARKOVIĆ V., LAZIĆ B., BOŠNJAK Đ. (2000): Effect of mineral nitrogen concetration in soil and irrigation on NO3 content in pateto tubers. Proc. 8th IS on Timing of field production in vegetables

IVANEK V. (1977): Mogućnosti procijene promjena botaničkog sastava u sijenu prirodnih zajednica utjecajem NP, NK a osobito NPK gnojidbe. Poljoprivredna znanstvena smotra, Zagreb, 41, 51: 15-26.

JEREMIĆ D. STOŠIĆ M. (1981): Proučavanje uticaja različitih nivoa azota u ishrani vrsta iz familije Fabaceae i Poaceae i njihovih smeša. Agrohemija, 11-12, 432-439.

KLAPP, E. (1971): Wiesen und Widen. Verlag Paul Parley. Berlin-Hamburg.

KOMAREK P., NERUŠIL P., KOHOUTEK A., ODSTRČILOVA V. (2007): The effect of repeated direct sowing of grass-legume seed mixtures into grasslands on forage production and quality. Grassland Science in Europa, 12, 39-42.

MALHI S.S., ZENTNER R.P., HEIER K. (2002): Effectiveness of alfalfa in reducing fertilizer $\mathrm{N}$ input for optimum forage yield, protein concentration, returns and energy performance of brome grass-alfalfa mixtures. Nutrient Cycling in Agroecosystems, 62, 219-227.

MARINKOVIĆ B., GRČIĆ S. (1993): Sadržaj nitrata u mleku u zavisnosti od sadržaja nitrata u stočnoj hrani i zemljištu. Savremena poljoprivreda, 1, 6, 205-208 NEŠIĆ Z., TOMIĆ Z., KRNJAJA V., TOMAŠEVIĆ D. (2008b): Nitrates in Plants and Soil After Fertilizarion of Grass-legume Mixtures. Biotechnology in Animal Husbandry, 24. 5-6, 95-104.

NIFELER D., HUGUENIN-ELIE O., SUTER M., FROSSARD E., LUSCHER A. (2008): Well-balanced grass-legume mixtures with low nitrogen fertilization can be as productive as highly fertilized grass monoculture. Grassland Science in Europe, 13, 197-199

NUTTALL W.F., D.H. MCCARTNEY S., BITTMAN P.R., HORTON AND J. WADDINGTON. (1991): The effect of N, P, S fertilizer, temperature, and precipitation on the yield of bromegrass and alfalfa pasture established on a Luvisolic soil. Canadian Journal of Plant Science, 71, 1047-1055.

OCOKOLJIĆ S., PARIS Z., VELIČKOVIĆ G., STOJANOVIĆ S. (1974): Ispitivanje uticaja kompleksnih mineralnih đubriva na prinos i kvalitet lucerke $\mathrm{i}$ smeše sa ježevicom. Arhiv za poljoprivredne nauke, 97, 73-82.

OCOKOLJIĆ S., VELIČKOVIĆ G., PARIS Z., NINKOVIĆ S. (1984a): Uticaj različitih nivoa đubrenja azotnim i NPK đubrivima na prinos, botanički i hemijski sastav i sadržaj nekih važnijih aminokiselina kod smeše ježevice (Dactylis glomerata) i žutog zvezdana (Lotus corniculatus). Agrohemija, 4, 265-274.

PETROVIĆ N., KASTORI, R. (2003): Nitrati u povrću. Naučni institut za ratarstvo i povrtarstvo Novi Sad, 116. 
PETROVIĆ M. (2007). Održivo ovčarstvo.

RAZEC M., RAZEC I., CHIPER C., OPREA G. (2002): Yield and quality forage improvement by N-use efficiencyin grass-cliver sward. Grassland Science in Europe, 7, 154-155.

RUŽIĆ-MUSLIĆ D., PETROVIĆ M.M., PETROVIĆ M.P., NEŠIĆ Z. (2006a): Ishrana kao faktor unapređenja proizvodnje ovčijeg mleka na području Stare planine. Biotehnologija u stočarstvu, vol 22, 5-6,55-63.

RUŽIĆ-MUSLIĆ D., PETROVIĆ M.M., PETROVIĆ M.P., NEŠIĆ Z. (2006b):New technological procedures nutrition of sheep for production of milk in region of Stara planina mountain. $9^{\text {th }}$ International Scientific Conference: Ecological issues of mountain agriculture, 28-29 may, Troyan. Journal of Mountain Agriculture on the Balkans, vol.9, 4, p. 624-639

RUŽIĆ-MUSLIĆ D.,.PETROVIĆ M.M., PETROVIĆ P.M., .ŽUJOVIĆ M., NEŠIĆ Z., MARINKOV G. (2007): Potential production of safe dairy products in hilly-mountainous region of Serbia. $10^{\text {th }}$ International Scientific Conference: Ecological issues of mountain agriculture, 28-29 may, Troyan. Journal of Mountain Agriculture on the Balkans, vol.10, 2, p (230-248)

RUŽIĆ-MUSIĆ D., PETROVIĆ P.M., BIJELIĆ Z. (2011a):Undegradable proteinimportant faktor in balancing of diets for fattening lambs. $3^{\text {rd }}$ INTERNATIONAL CONGRESS"New perspectives and Challenges of Sustainable Livestock Production", OCTOBER 2009, BELGRADE. Biotechnology in Animal Husbandry Book 1, 27 (3), 473-485

RUŽIĆ-MUSLIC D., PETROVIC M.M., PETROVIC P.M., BIJELIC Z, PANTELIC V., PERIŠIC P., BOGDANOVIĆ V. (2011b):Traditional production and characteristics of Sjenica cheese and Pirot kachkaval.Bulgarian Journal of Agricultural Science.Vol 17 (5), Septembar,2011, 664-672.Agricultural Academy.

SHIEL R.S., TILIB A.B.A., YOUNGER A. (1999): The influence of fertilizer nitrogen, white clover content and environmental factors on the nitrate content of perennial ryegrass and ryegrass/white clover swards. Grass and Forage Science, 54, 275-285.

STANTON, L.T. (2001). Nitrate poisoning. Colorado State University Extension, No.1.610.

STOLTENOW C., LARDY, G. (1998): Nitrate Poisoning of Livestock. NDSU Extension Service, Nort Dakota State University, Fargo, ND 58105. http://www.ag.ndsu.edu/pubs/ansci/livestoc/v839w.htm

STOŠIĆ M., LAZAREVIĆ D., DINIĆ B. (1996): Ispitivanje uticaja sistema iskorišćavanja sejanog travnjaka na njegove proizvodne karakteristike i stočarsku proizvodnju. Zbornik radova, VIII-og jugoslovenskog simpozijuma o krmnom bilju, 26, 541-547.

STOŠIĆ M., LAZAREVIĆ D., DINIĆ B., MARTINOV S., DEDIĆ T., HODŽIĆ E. (2006): Savremene tehnologije u proizvodnji i konzervisanju biomase sa 
travnjaka i oranica na sjeničko-pešterskoj visoravni.Biotehnologija u stočarstvu, vol. 22, s.i., p.499-512.

STOUT W. L., WEAVER S. R., ELWINGER G. F. (2001): Effects of early season nitrogen on grass -clover swards in the Northeastern Usa. Agronomy Journal, 93, 1000-1005.

STRINGER W.C., MORTON B.C., PINKERTON B.W. (1996): Row spacing and nitrogen: Effect on alfalfa - bermudagrass quality components. Agronomy Journal, 88, 573-577.

VUČKOVIĆ, S. (1999): Krmno bilje. Institut za istraživanje u poljoprivredi "Srbija", 553

VUČKOVIĆ, S. (2004): Travnjaci. Poljoprivredni fakultet- Univerzitet u Beogradu, 488.

ŠOŠTARIĆ-PISAČIĆ K., KOVAČEVIĆ J.(1968): Travnjačka flora i njena poljoprivredna vrednost. Nakladni zavod Znanje, Zagreb.

Received 19. February 2012; accepted for publication 21. May 2012 